\title{
Improvement of the Physicochemical Properties of Distilled Products of Petroleum (Diesel, JP-8) and Mix Diesel-Biodiesel by Using European Black Pine Oleoresin
}

\author{
Constantinos Tsanaktsidis ${ }^{1}$, Adams Stimoniaris ${ }^{2}$, Spyros Bousios ${ }^{3}$, George Tzilantonis ${ }^{1}$, \\ Athanasios Scaltsoyiannes ${ }^{4}$, Maria Taktsira ${ }^{5}$, Apostolos Scaltsoyiannes ${ }^{5}$ \\ ${ }^{1}$ Laboratory of Qualitative Fuel Control, Department of Environmental Engineering and Pollution Control and \\ Technologies, Technological Education Institute of Western Macedonia, Kozani, Greece \\ ${ }^{2}$ Laboratory of Nanotechnology and Advanced Materials, Department of Environmental Engineering and \\ Pollution Control and Technologies, Technological Education Institute of Western Macedonia, \\ Kozani, Greece \\ ${ }^{3}$ Forest Department of Kozani, Decentralized Administration of Epirus and Western Macedonia, \\ Kozani, Greece \\ ${ }^{4}$ Department of Chemical Engineering, Aristotle University of Thessaloniki, Thessaloniki, Greece \\ ${ }^{5}$ Laboratory of Forest Genetics and Plant Breeding, Department of Forestry and Natural Environment, Aristotle \\ University of Thessaloniki, Thessaloniki, Greece \\ Email: *tsanaktsidis@teiwm.gr, astim@teiwm.gr, spyrusbousios@gmail.com, \\ skaltsoy@for.auth.gr, ascaltso@gmail.com
}

Received 19 January 2016; accepted 28 March 2016; published 31 March 2016

Copyright (C) 2016 by authors and Scientific Research Publishing Inc.

This work is licensed under the Creative Commons Attribution International License (CC BY). http://creativecommons.org/licenses/by/4.0/

(c) (i) Open Access

\section{Abstract}

One of the important stages in the preparation of fuel for the smooth progress of combustion is to remove humidity from it. Natural resin, a natural product from Pinus nigra was used in order to remove water residues from petroleum fuels. The mass of resin was mixed with diesel fuel, JP-8, and mix diesel-biodiesel and main physicochemical properties measured and compared with those of the raw fuels were measured. The humidity eliminated $38 \%$ of diesel, $21 \%$ of jet fuel, and $30 \%$ of mix diesel-biodiesel $(80 \%-20 \%)$ and improved the physicochemical properties. The resin can be replaced and re-generated as often needed.

\footnotetext{
${ }^{*}$ Corresponding author.
}

How to cite this paper: Tsanaktsidis, C., et al. (2016) Improvement of the Physicochemical Properties of Distilled Products of Petroleum (Diesel, JP-8) and Mix Diesel-Biodiesel by Using European Black Pine Oleoresin. Journal of Environmental Protection, 7, 583-590. http://dx.doi.org/10.4236/jep.2016.75052 
Keywords

Pinus nigra, Fuel, Humidity, Physicochemical Properties

\section{Introduction}

The growth technology of removing humidity from liquid petroleum distillates with very high commercial value but also other fuels (biofuels), such as diesel, kerosene (Jet Fuels) and also mixtures biodiesel/diesel is the object of this work. The humidity is one of the important points for incomplete combustion but also for the general erosion of motors, piping and storage tanks. There are a few techniques methods, which are used in order to eliminate humidity [1]-[3], but characterized by high cost, long duration and controlled output, while they could not encounter the phenomenon in its entirety, since humidity can appear after the stage of the distillation of crude oil and at all phases of production and transportation of fuels. The improvement of the physicochemical properties of the fuels gives benefits to the total amount of the required fuels as well as to the protection of the environment due to the purity of the exhaust [4]. On the other hand there are a few recent studies which focus on the problem to the point [5].

Recently published research papers are on the effects of halepensis pine resin to remove humidity [5] [9], especially the natural resin as a natural material capable of being used as an improver of fuel physicochemical properties is based on the capacity to absorb natural processes of water molecules on its surface. This property is due to the chemistry of natural resin consisted of mono and di-terpenes which have many functional groups such as hydroxyls and carboxyls, groups that bear the primary responsibility for the physical adsorption of water [5]. The present study extends this research and natural resin derived from the black pine to cover all types of pine found in the wider Balkan region producing resin. Also the use of black pine in restoring land that has been used in the production of fossil fuels such as lignite, is easier with black pine as it can thrive in rough terrain. Finally, the greater capacity of the black pine to bind $\mathrm{CO}_{2}$ makes the important factor to climate change in the region.

Pine oleoresin (natural resin) is a secondary product of pine trees and generally all conifers. Resin as a natural forestry renewable resource is considered a product of significant economic value worldwide, since it is the raw material for the production of numerous secondary chemical, high added-value products. It is contained within the resin canals of trees and usually is harvested by tapping [6]. Oleoresin is produced by specialized epithelial cells within the xylem and stored within vertical resin ducts in the stems, roots, needles and cones of conifer trees [7], resin flow from existing (constitutive or primary resin) or traumatic (induced or secondary resin) resin canals [8]. In the industry, the crude oleoresin is converted by steam distillation into gum turpentine (volatile compounds) and gum rosin (diterpenes).

The possibility to use natural resin as a natural material to improve the fuel's quality is based on its capacity to adsorb water molecules on its surface. An initial study of this phenomenon was performed by using natural resin from pinus halepensis trees and showed that the use of resin can reduce the moisture in petroleum distillates and improve other physicochemical properties [5] [9].

European black pine (Pinus nigra Arnold) is one of the most valuable and widespread conifer species in the Mediterranean region and is distributed in a discontinuous area which includes Southern Europe, Minor Asia, Cyprus and North-Western Africa [10]. According to many authors P. nigra is a typical Mediterranean species and is regarded as a relict species of the Tertiary period. Because of the pattern of its natural distribution, black pine is considered to be a variable species. This is also indicated by the large number of taxa (subspecies, varieties and forms) [11]-[13].

A few studies reported the chemical composition of resins of Pinus nigra [14]-[16]. The chemometric analysis of the black pine oleoresin, identified 15 compounds, i.e. eight resinic acids (abietic acid, dehydroabietic acid, neoabietic acid, palustric acid, levopimaric acid, isopimaric acid, pimaric acid and sandaracopimaric acid), six neutral diterpenes (pimaral, pimarol, isopimaral, isocembrol, 4-epi-isocembrol and cembrene) and one monoterpene ( $\alpha$-pinene) [14].

In this study natural resin, from Pinus nigra, one of the most widely distributed pines species in the Mediterranean region, was used as a renewable, removable, additive in order to improve the physicochemical properties of fuels. The effect of the resin blending with commercial fuels on physicochemical properties, of the diesel fuel, jet fuel, and mix diesel-biodiesel is also presented. 
The present study extends the previous work with $P$. halepensis [5] [9] by using natural resin derived from Pinus nigra a species that grows in different environmental conditions (harsh soils and low temperatures) than the typical European resinous species (P. halepensis, P. maritima, P. brutia).

Diesel fuel, JP-8 and Biodiesel are mixtures of different hydrocarbons, organic compounds and must satisfy a wide range of various engine types, in different operating conditions and duty cycles [17] [18].

Water is mainly responsible for corrosion in engines, storage and transport reservoirs [19] [20]. Also ice formed at low temperatures results in fuel flow blockages, which is a major problem, especially in the new types of diesel engines.

Finally the natural resin, from Pinus nigra, is one of the most widely distributed pines pieces in Greece and Mediterranean region, which could be used as a recyclable, removable, additive in order to eliminate humidity and improve the physicochemical properties of commercial fuels.

The effect of the resin from Pinus nigra on humidity, blending with commercial fuels (diesel fuel, jet fuel, and mix diesel-biodiesel), is presented. In this methodology the resin can be used, directly, as water adsorbed material and improve the fuels physicochemical properties and financial cost.

\section{Experimental}

\subsection{Materials}

Natural resin was collected during summer period from natural forest of P. nigra of North-West Greece (Public forest Katafigiou—Agias Kiriakis Kozani-Greece) (Figure 1) and the liquid fuels (diesel, biodiesel) were supplied by the Hellenic Petroleum company.

Natural resin (concentration of $0.5 \% \mathrm{w} / \mathrm{v}$ ) was mixed with the tested fuels (diesel, JP-8 and mix diesel-biodiesel) for $2 \mathrm{~h}$ and then removed mechanically. The main physicochemical properties (density, kinematic viscosity, conductivity, humidity, flash point, heat of combustion) were measured, according to the ASTM standard methods [21]-[27], and compared with those of untreated fuels.

\subsection{Physicochemical Properties of Liquid Fuels}

The physicochemical properties of conventional diesel fuel, distilled biodiesel and JP8 fuels and its methods of determination are presented below Table 1.

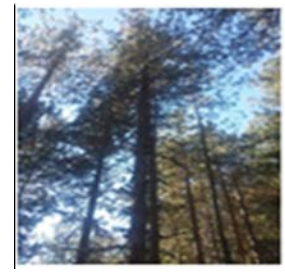

(a)

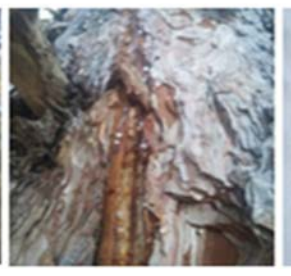

(b)

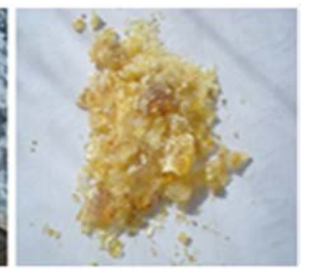

(c)

Figure 1. (a) and (b) The black pine (Pinus nigra Arnold) is one of the most widespread Mediterranean conifer species of mountainous areas; (c) Oleoresin (natural resin) of Pinus nigra Arnold.

Table 1. Values of physicochemical properties of conventional diesel, biodiesel and JP8 fuels and its methods of determination.

\begin{tabular}{cccccccc}
\hline & \multicolumn{2}{c}{ DIESEL } & \multicolumn{2}{c}{ JET FUEL } & \multicolumn{3}{c}{ BIODIESEL } \\
\cline { 2 - 8 } & diesel & Limits & JP8 & Limits & biodiesel & Limits biodiesel & Method \\
\hline Density $15^{\circ} \mathrm{C} \mathrm{g} / \mathrm{mL}$ & 0.827 & $0.820-0.845$ & 0.800 & $0.775-0.840$ & 0.863 & $0.860-0.900$ & ASTM D1298 \\
API Gravity $60^{\circ} \mathrm{F}$ & 39.6 & $35.9-41.0$ & 45.3 & $37.0-51.0$ & - & - & ASTM D4052 \\
Kinematic Viscosity $40^{\circ} \mathrm{C} \mathrm{mm} / \mathrm{s}$ & 2.940 & $2.00-4.50$ & - & - & 3.97 & $3.50-5.00$ & ASTM D445 \\
Flash Point ${ }^{\circ} \mathrm{C}$ & 60 & $>55$ & 50 & $>38$ & 114 & $>101$ & ASTM D93 \\
Conductivity $\mathrm{pS} / \mathrm{m}$ & 465 & $<1000$ & 15 & $<1$ & 470 & - & ASTM D2624 \\
Water content $\mathrm{mg} / \mathrm{kg}$ & 72 & $<200$ & 48.5 & $<50$ & 320 & $<500$ & ASTM D1744 \\
Heat of Combustion J/g & 44,200 & $>42,600$ & 46,167 & $>42,800$ & 39,935 & $>35,000$ & ASTM D4809 \\
\hline
\end{tabular}


According with the Table 1 we can observe that while the values of the properties for the fuels are within limits suitability for biodiesel in the value of the humidity is very high (because of limits suitability $<500$ ). This is the big problem when mixing with diesel fuel and the production of ended products. The final blend diesel-biodiesel can often contain humidity outside the limits if situated within limits to be very high value, with result to be generated a problem in the course of combustion, to the protection the machine and of course to the produced energy. For this reason it is necessary the use of the P. nigra so as to the final mixture have low humidity.

\subsection{Techniques for the Resin of Pinus Nigra Characterization.}

The Differential Scanning Calorimetry (DSC) measurements were performed using a temperature-modulated differential scanning calorimetry (BÄHR-Thermoanalyse GmbH, DSC 302). The Thermogravimetric analysis (TGA) spectrums were obtained in a TGA/DTA Thermogravimetric/Differential Thermal Analyzer (TA Instruments, Model Q500) using inert environment (Ar, $10 \mathrm{ml} / \mathrm{min}$ ), platinum crucibles, a heating rate of $2^{\circ} \mathrm{C} / \mathrm{min}$ and a sample mass of $\sim 60 \mathrm{mg}$.

\section{Results and Discussion}

\subsection{The Effect of the Pinus nigra Resin in Physicochemical Properties of Fuels before and after the Treatment}

Choosing the concentration of $0.5 \%(\mathrm{w} / \mathrm{v})$ of the resin in the fuel (5 g resin in1000 $\mathrm{ml}$ fuel sample) anassiduous study of the standard physicochemical properties of the fuels was evaluated. All the measurement properties, the density at $15^{\circ} \mathrm{C}$, the kinematic viscosity at $40^{\circ} \mathrm{C}$, the conductivity, the humidity, the flash point, the heat of combustion, at three different rates of recovery, were evaluated using the ASTM methods. Values of physicochemical properties of conventional diesel fuel, and JP8, mix diesel-biodiesel (80 - 20)\% fuels before and after the treatment pinus nigra and its methods of determination are presented below, Table 2 and Table 3.

These experiments were performed three times and the values in Table 3 are the averages of these measurements. The repeatability of the measurements was about $\pm 0.5 \%$. As we can see in the Table 3 all the studied physicochemical properties of the commercial fuels, diesel, JP-8 and also the mix diesel-biodiesel (80 - 20)\% were increased after the mixing process with the resin additives. Comparing the values of water contents of Table 3, with those of previous work [5] [9] we found them lower, probably, due to the fact that P. nigra has less number of polar groups (carboxyl groups) instead the resin from halepensis pine [1] [2] [28]. Also, the black pine completely missing the group of seq-terpens equipped polar groups of the category of Hydrocarbon-OH.

The benefits, which occurred thanks to the improvement of the properties, give to the sample a series of advantages both for economical and environmental impact. Especially the reduction of the humidity, of the low conductivity and the flash point, may not only affect several functions (reduce icing effect, avert corrosion during storage), but also could make safer the fuel handling and storage because the flash point is the lowest fuel temperature at which the vapour above the fuel sample level (in the liquid phase) will momentarily ignite under the prescribed test conditions. Furthermore this lower conductivity could improve the dissipation of the static charge. Properties such as conductivity, humidity, flash point and heat of combustion had a better level in the case of the treatment fuel samples.

Table 2. Values of water content diesel, JP8, and mix diesel-biodiesel (80 - 20)\% fuels before and after the treatment Pinus nigra and its methods of determination.

\begin{tabular}{|c|c|c|c|c|c|c|c|c|c|c|}
\hline & Diesel & $\begin{array}{l}\text { Diesel } \\
+ \\
\text { Pinus } \\
\text { nigra }\end{array}$ & Limits & JP8 & $\begin{array}{c}\text { JP8 } \\
+ \\
\text { Pinus } \\
\text { nigra }\end{array}$ & Limits & $\begin{array}{c}\text { Mix } \\
\text { diesel-biodiesel } \\
(80-20) \%\end{array}$ & $\begin{array}{c}\text { Mix } \\
\text { diesel-biodiesel } \\
(\mathbf{8 0 - 2 0 )} \%+ \\
\text { Pinus nigra }\end{array}$ & Limits & Method \\
\hline $\begin{array}{l}\text { Density } \\
15^{\circ} \mathrm{C} \mathrm{g} / \mathrm{mL}\end{array}$ & 0.819 & 0.817 & $0.820-0.845$ & 0.800 & 0.797 & $0.775-0.840$ & 0.823 & 0.822 & $0.820-0.845$ & $\begin{array}{l}\text { ASTM } \\
\text { D1298 }\end{array}$ \\
\hline $\begin{array}{c}\text { Water } \\
\text { content } \\
\text { mg/kg }\end{array}$ & 72 & 45.1 & $<200$ & 48.5 & 38.6 & $<50$ & 182 & 127 & $<200$ & $\begin{array}{l}\text { ASTM } \\
\text { D1744 }\end{array}$ \\
\hline
\end{tabular}


Table 3. Values of physicochemical properties of conventional diesel fuel, and JP8, mix diesel-biodiesel (80 - 20)\% fuels before and after the treatment pinus nigra and its methods of determination.

\begin{tabular}{|c|c|c|c|c|c|c|c|c|c|c|}
\hline & Diesel & $\begin{array}{c}\text { Diesel } \\
+ \\
\text { Pinus } \\
\text { nigra }\end{array}$ & Limits & JP8 & $\begin{array}{c}\text { JP8 } \\
+ \\
\text { Pinus } \\
\text { nigra }\end{array}$ & Limits & $\begin{array}{c}\text { Mix } \\
\text { diesel-biodiesel } \\
(80-20) \%\end{array}$ & $\begin{array}{c}\text { Mix } \\
\text { diesel-biodie } \\
\text { sel } \\
(80-20) \% \\
\text { + pinus } \\
\text { nigra }\end{array}$ & $\begin{array}{l}\text { Limits } \\
\text { diesel }\end{array}$ & Method \\
\hline $\begin{array}{l}\text { Density } \\
15^{\circ} \mathrm{C} \mathrm{g} / \mathrm{mL}\end{array}$ & 0.827 & 0.817 & $0.820-0.845$ & 0.80 & 0.797 & $0.775-0.840$ & 0.823 & 0.822 & $0.820-0.845$ & ASTM D1298 \\
\hline $\begin{array}{c}{ }^{\circ} \text { API Gravity } \\
60^{\circ} \mathrm{F}\end{array}$ & 39.6 & 39.2 & $35.9-41.0$ & 45.3 & 46.5 & $37.0-51.0$ & - & - & $35.9-41.0$ & ASTM D4052 \\
\hline $\begin{array}{l}\text { Kinematic } \\
\text { Viscosity } \\
40^{\circ} \mathrm{C} \mathrm{mm} / \mathrm{s}\end{array}$ & 2.940 & 2.54 & $2.00-4.50$ & - & & - & 2.97 & 2.95 & $2.00-4.50$ & ASTM D445 \\
\hline Flash Point ${ }^{\circ} \mathrm{C}$ & 60 & 57 & $>55$ & 50 & 48 & $>38$ & 65 & 57 & $>55$ & ASTM D93 \\
\hline $\begin{array}{c}\text { Conductivity } \\
\text { pS/m }\end{array}$ & 465 & 408 & $<1000$ & 15 & 6 & $<1$ & 470 & 434 & $<1000$ & ASTM D2624 \\
\hline $\begin{array}{c}\text { Water } \\
\text { Content mg/kg }\end{array}$ & 72 & 45.1 & $<200$ & 48.5 & 38.6 & $<50$ & 182 & 127 & $<200$ & ASTM D1744 \\
\hline $\begin{array}{c}\text { Heat of } \\
\text { Combustion } \\
\mathbf{J} / \mathrm{g}\end{array}$ & 44,200 & 45,043 & $>42,600$ & 46,167 & 46,230 & $>42,800$ & 43,833 & 43,932 & $>42,600$ & ASTM D4809 \\
\hline
\end{tabular}

The stability of used natural compound in conjunction with high hydrophilic properties enables the resin being capable as an additive material in fuel improvement process. Therefore the experimental results proved that the use of resin instead of other techniques could be more efficient and economical. Specially, the multiple capability of the material regeneration makes this technique more efficient and the resin could be used during the transportation of fuels or in the storage tanks in order to reduce, even to eliminate, the amount of humidity in short time before the fuels are used. This can happen with a limited cost which focuses mainly on the cost of the process of the resin picking.

\subsection{Differential Scanning Calorimetry}

Two runs were performed in the DSC experimental setup with the same process us reported in a previews paper [5], and both curves present similar endothermic behaviour during the first heating. During the second heating process the endothermic peak observed for each studied sample in the temperature region from $225^{\circ} \mathrm{C}$ to $330^{\circ} \mathrm{C}$. These curves attributed to the endothermic phenomenon of the relaxation, deformation, of the polymeric chains. Especially in the case of the raw resin sample the required heat (energy) is $69.22 \mathrm{~J} / \mathrm{g}$, while $50.34 \mathrm{~J} / \mathrm{g}$ in case of the sample which was used in diesel blending process (treatment sample). This difference in required energy of the chain relaxation occurs due to the swelling phenomenon of the resin material when it's in the diesel fuel Figure 2.

As shown in Figure 3, the peaks of these endothermic curves appeared at $278.9^{\circ} \mathrm{C}$ and $281.6^{\circ} \mathrm{C}$ for the treatment and un-treatment resin samples respectively. These temperatures as the melting transition points for each studied sample are about $20^{\circ} \mathrm{C}$ higher than the Pinus halepensis [5].

\subsection{Thermogravimetric Analysis}

Both resin samples ( $60 \mathrm{mg}$ ) were heated with the same experimental setup process us reported in a previews paper [5]. As we can see in Figure 3, there are three main weight-loss stages for both resin samples. The first weight loss occurs below $120^{\circ} \mathrm{C}$ and is attributed to the evaporation of the adsorbed water. The second weight loss, $40 \%$ from $120^{\circ} \mathrm{C}$ to $270^{\circ} \mathrm{C}$ in the case of both resin samples take place with the same way. The third weight loss, $\sim 89.5 \%$, from $270^{\circ} \mathrm{C}$ to $400^{\circ} \mathrm{C}$ in the case of the pure resin sample and from $270^{\circ} \mathrm{C}$ to $360^{\circ} \mathrm{C}$ in the case of the pure resin sample, is attributed to the relaxation of the polymeric chains and "plasticization" transition, pre-carbon formation, for both samples (see also DSC diagram Figure 2). This transition occurs in higher 


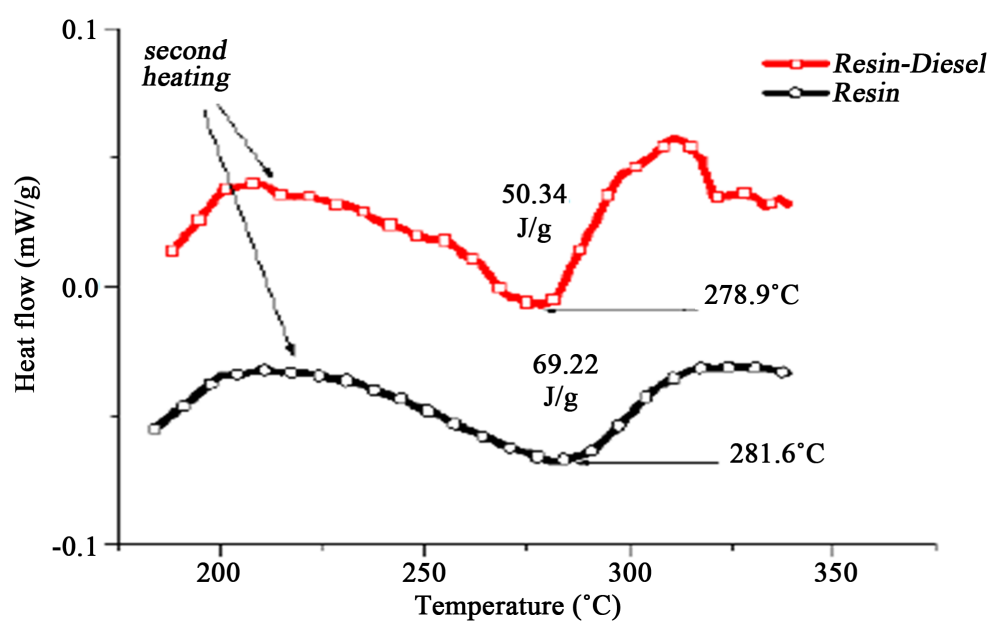

Figure 2. DSC curves for the natural resin and the resin after mixing with diesel samples.

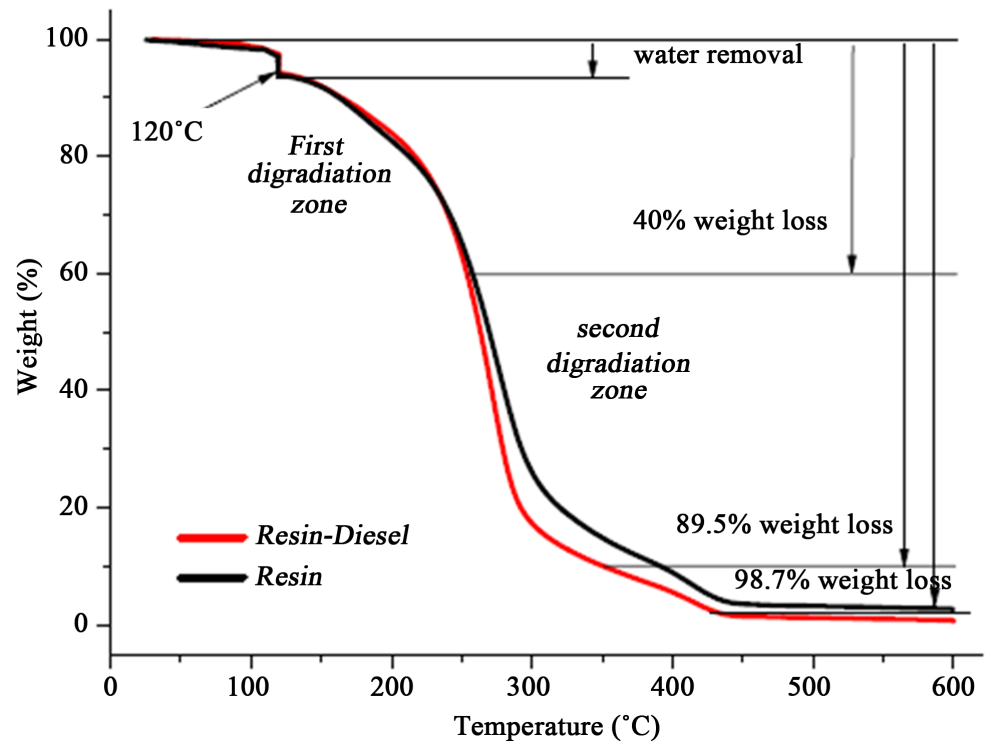

Figure 3. TGA curves for the natural resin and the resin after mixing with diesel samples.

temperature, about $50^{\circ} \mathrm{C}$, for both samples of Pinus nigra in comparison of the Pinus halepensis "plasticization" [5]. Finally the forth weight loss zone is attributed to the degradation of the structure when the $98.7 \%$ of the total weight is lost. As we can see, after the temperature of $430^{\circ} \mathrm{C}$ all the differences between the two curves disappear and both curves present the same transition. In this region, $430^{\circ} \mathrm{C}-600^{\circ} \mathrm{C}$, the mass of the samples was destroyed and only about $1.3 \%$ of the total mass remained.

\section{Conclusions}

The present study was an attempt to establish the possibility to use crude natural resins of $P$. nigra as a candidate material for antifouling fuel technology. The crude natural resin was used as a humidity/water adsorbent in order to purify commercial fuels and mix. The above methodology gives the opportunity to remove humidity of the liquid fuels (Diesel-JP-8) and mix Diesel-Biodiesel and the whole method is an environmental clean technologies segment.

All the physicochemical properties of the tested fuels were positively affected. Specifically, we show that the humidity eliminated 38\%, 20\% and 30\% for the diesel fuel, jet fuel and mix diesel-biodiesel (80\% - 20\%) respectively. Also, the other physicochemical properties of the fuels were improved after the mixing with the resin 
additive. In particular, notice that the conductivity reduced up to 67, 9, $36 \mathrm{pS} / \mathrm{m}$ for the diesel fuel, jet fuel and mix diesel-biodiesel (80\% - 20\%) respectively and the heat of combustion increased by 843, 63, $99 \mathrm{~J} / \mathrm{g}$ for the tree types of fuels. The used material (resin) is renewable, low cost, harmless and environmentally friendly.

The proposed technique can be of interest for the fuel community and industry because it's quite simple as well as because of the superfluity and the low cost of the natural resin in Greece.

\section{References}

[1] Pakula, B.J. (1987) System for Removal of Water from Diesel Fuel Systems. US Patent, 4637351.

[2] Thomas, E. (1992) Removal of Water Haze from Distillate Fuel. European Patent Office, 0290163B1.

[3] Jensen, H., Xia, Z.X. and Mulkeran, K. (2008) Separated Water Treatment System for Diesel Fuel Engine. US Patent, 2008/0110812 A1.

[4] Jaworek, A., Krupa, A. and Czech, T. (2007) Modern Electrostatic Devices and Methods for Exhaust Gascleaning: A Brief Review. Journal of Electrostatics, 65, 133-155. http://dx.doi.org/10.1016/j.elstat.2006.07.012

[5] Tsanaktsidis, C.G., Favvas, E.P., Scaltsoyiannes, A.A., Christidis, S.G., Katsidi, E.X. and Scaltsoyiannes, A.V. (2013) Natural Resins and Their Application in Antifouling Fuel Technology: Part I: Improving the Physicochemical Properties of Diesel Fuel Using Natural Resin Polymer as a Removable Additive. Fuel Processing Technology, 114, 135-143.

[6] Rodrigues-Corrêa, K.C.S., Lima, J.C. and Fett-Neto, A.G. (2012) Pine Oleoresin: Tapping Green Chemicals, Biofuels, Food Protection, and Carbon Sequestration from Multipurpose Trees. Food and Energy Security, 1, 81-93. http://dx.doi.org/10.1002/fes3.13

[7] Esau, K. (1965) Plant Anatomy. 2nd Edition, John Wiley, New York.

[8] Barbosa, P. and Wagner, M.R. (1989) Introduction to Forest and Shade Tree Insects. Academic Press, San Diego, 150-167. http://dx.doi.org/10.1016/B978-0-12-078146-1.50011-0

[9] Tsanaktsidis, C.G., Scaltsoyiannes, A.V., Katsidi, E.X., Christidis, S.G. and Tzilantonis, G.T. (2014) Use of Natural Resin to Reduce Water Content in Diesel Fuel. Chemistry and Technology of Fuels and Oils, 49, 497-501. http://dx.doi.org/10.1007/s10553-014-0475-7

[10] Critchfield, W.B. and Little, E.L. (1966) Geographic Distribution of the Pines of the World. No. 991. US Department of Agriculture, Forest Service.

[11] Tsaktsira, M. (1992) Variation Isoenzymatique Inter-, Intra-Populations de Pinus nigra ARNOLD et contribution des isoenzymes a l' etude taxonomique se cette espece. Mémoire presente devant l' Universite Claude-Bernard, Lyon I, pour obtenir le D.E.S., Lyon, 117 p.

[12] Scaltsoyiannes, A., Rohr, R., Panetsos, K.P. and Tsaktsira, M. (1994) Allozyme Frequency Distributions in Five European Populations of Black Pine (Pinus nigra Arnold). I. Estimation of Genetic Variation within and among Populations. II. Contribution os Isozyme Analysis to the Taxonomic Status of the Species. Silvae Genet., 43, 20-30.

[13] Scaltsoyiannes, A., Tsaktsira, M., Pasagiannis, G., Tsoulpha, P., Zhelev, P., Iliev, I. and Rohr, R. (2009) Allozyme Variation of European Black (Pinus nigra Arnold) and Scots Pine (Pinus sylvestris L.) Populations and Implications on Their Evolution: A Comparative Study. Journal of Biological Research, 11, 95-106.

[14] Rezzi, S., Bighelli, A., Castola, V. and Casanova, J. (2005) Composition and Chemical Variability of the Oleoresin of Pinus nigra ssp. laricio from Corsica. Industrial Crops and Products, 21, 71-79.

[15] Iconomou, N. and Valkanas, G. (1966) Uber die Zusammensetzung des harzbalsams einiger Pinus-Arten Griechenlands. Pharmaceutica Acta Helvetiae, 41, 59-63.

[16] Cannac, M., Barboni, T., Ferrat, L., Bighelli, A., Castola, V., Costa, J., Trecul, D., Morandini, F. and Pasqualini, V. (2009) Oleoresin Flow and Chemical Composition of Corsican Pine (Pinus laricio) in Response to Prescribed Burnings. Forest Ecology and Management, 257, 1247-1254. http://dx.doi.org/10.1016/j.foreco.2008.11.017

[17] Santana, R.C., Do, P.T., Santikunaporn, M., Alvarez, W.E., Taylor, J.D., Sughrue, E.L., et al. (2006) Evaluation of Different Reaction Strategies for the Improvement of Cetane Number in Diesel Fuels. Fuel, 85, 643-656. http://dx.doi.org/10.1016/j.fuel.2005.08.028

[18] Brown, R.L. and Wines, J.T.H. (1993) A Better Understanding of Molecular Forces Enhances Free Water Separator Selection. Hydrocarbon Processing, 95-99.

[19] Sarvi, A., Fogelholm, C. and Zevenhoven, R. (2008) Emissions from Large-Scale Medium-Speed Diesel Engines: 2. Influence of Fuel Type and Operating Mode. Fuel Processing Technology, 89, 520-527.

[20] Taflan, R.A. and Karamangil, M.I. (2012) Statistical Corrosion Evaluation of Nozzles Used in Diesel CRI Systems. Fuel, 102, 41-48. http://dx.doi.org/10.1016/j.fuel.2012.06.037 
[21] ASTM D1298-99 (2005) Standard Test Method for Density Relative Density (Specific Gravity), or API Gravity of Crude Petroleum and Liquid Petroleum Products by Hydrometer Method.

[22] ASTM D4052-2011 (2011) Standard Test Method for Density, Relative Density, and API Gravity of Liquids by Digital Density Meter.

[23] ASTM D445-06 (2006) Standard Test Method for Kinematic Viscosity of Transparent and Opaque Liquids (and Calculation of Dynamic Viscosity).

[24] ASTM D93-2013 (2013) Standard Test Methods for Flash Point by Pensky-Martens Closed CupTester, ASTM International, http://dx.doi.org/10.1520/D0093

[25] ASTM D2624-02 (2002) Standard Test Methods for Electrical Conductivity of Aviation and Distillate Fuels.

[26] ASTM D1744-1992 (1992) Standard Test Method for Determination of Water in Liquid Petroleum Products by Karl Fischer Reagent (Withdrawn 2000).

[27] ASTM D4809-2013 (2013) Standard Test Method for Heat of Combustion of Liquid Hydrocarbon Fuels by Bomb Calorimeter (Precision Method).

[28] Karanikas, C., Walker, V., Scaltsoyiannes, A., Compte, G. and Betrand, C. (2010) High vs Low Yielding Oleoresin Pinus halepensis Mill. Trees. GC Terpenoids Profiling as Diagnostic Tool. Annals of Forest Science, 67, 412-419. http://dx.doi.org/10.1051/forest/2009132 